\title{
MAP4K4 wt Allele
}

National Cancer Institute

\section{Source}

National Cancer Institute. MAP4K4 wt Allele. NCI Thesaurus. Code C52826.

Human MAP4K4 wild-type allele is located within 2q11.2-q12 and is approximately $197 \mathrm{~kb}$ in length. This allele, which encodes mitogen-activated protein kinase kinase kinase kinase 4 protein, may play a role in tumor necrosis factor-alpha signaling through the regulation of the activity of mitogen-activated protein kinase 8. 